OPEN ACCESS

Edited by:

Harriët Jager-Wittenaar,

Hanze University of Applied

Sciences, Netherlands

Reviewed by:

Mar Ruperto,

CEU San Pablo University, Spain

Denise Philomene Joseph Van

Aanholt,

University of São Paulo, Brazi

*Correspondence:

Lenore Dedeyne

Lenore.dedeyne@kuleuven.be

Specialty section:

This article was submitted to

Clinical Nutrition,

a section of the journal

Frontiers in Nutrition

Received: 26 February 2021

Accepted: 08 July 2021

Published: 09 August 2021

Citation:

Dedeyne L, Dupont J, Verschueren S, Koppo K, Tournoy J, Matthys C and Gielen E (2021) Personalized Protein

Supplementation Improves Total Protein, Leucine, and Energy Intake in (Pre)Sarcopenic Community-Dwelling

Older Adults in the ENHANce RCT.

Front. Nutr. 8:672971.

doi: 10.3389/fnut.2021.672971

\section{Personalized Protein} Supplementation Improves Total Protein, Leucine, and Energy Intake in (Pre)Sarcopenic Community-Dwelling Older Adults in
the ENHANce RCT

\author{
Lenore Dedeyne $^{1 *}$, Jolan Dupont ${ }^{1,2}$, Sabine Verschueren ${ }^{3}$, Katrien Koppo ${ }^{4}$, \\ Jos Tournoy ${ }^{1,2}$, Christophe Matthys ${ }^{5,6}$ and Evelien Gielen ${ }^{1,2}$
}

${ }^{1}$ Gerontology and Geriatrics, Department of Public Health and Primary Care, Katholieke Universiteit Leuven, Leuven, Belgium, ${ }^{2}$ Department of Geriatric Medicine, UZ Leuven, Leuven, Belgium, ${ }^{3}$ Department of Rehabilitation Sciences, Katholieke Universiteit Leuven, Leuven, Belgium, ${ }^{4}$ Exercise Physiology Research Group, Department of Movement Sciences, Katholieke Universiteit Leuven, Leuven, Belgium, ${ }^{5}$ Clinical and Experimental endocrinology, Department of Chronic Diseases, Metabolism and Ageing (CHROMETA), Katholieke Universiteit Leuven, Leuven, Belgium, ${ }^{6}$ Department of Endocrinology, UZ Leuven, Leuven, Belgium

Recommendations concerning protein quantity, source, and leucine intake for older adults are difficult to reach by regular dietary intake. This randomized clinical trial assesses in sarcopenic community-dwelling older adults (i) the regular (non-supplemented) daily protein and leucine intake; and (ii) the effect of personalized protein supplementation (aiming for an evenly distributed total protein intake of $1.5 \mathrm{~g} \cdot \mathrm{kg}^{-1} \cdot \mathrm{d}^{-1}$ of body mass, accounting for energy intake) on regular and total (dietary and supplemental) intake. A preliminary feasibility study in participants of the ongoing Exercise and Nutrition for Healthy AgeiNg (ENHANce) study was performed with the objective to assess the intake and distribution of regular dietary protein and leucine, protein source and energy intake in (pre)sarcopenic community-dwelling older adults. Moreover, this study aimed to assess if personalized protein supplementation was feasible without negatively affecting regular dietary intake. ENHANce (NCT03649698) is a 5-armed RCT that assesses the effect of anabolic interventions on physical performance in (pre)sarcopenic older adults. In August 2019, $n=51$ participants were included in ENHANce with complete available data on dietary intake at screening and thus eligible for inclusion in present analysis. Of these, $n=35$ participants completed the intervention period of ENHANce at the moment of analysis, allowing an exploration of the effect of supplementation on regular dietary intake. The regular dietary protein intake of 51 (pre)sarcopenic adults (73.6 \pm 6.5 years) was $1.06 \pm 0.3 \mathrm{~g} \cdot \mathrm{kg}^{-1} \cdot \mathrm{d}^{-1}$ of body mass. Protein supplementation $(n=$ 20) improved total protein intake to $1.55 \pm 0.3 \mathrm{~g} \cdot \mathrm{kg}^{-1} \cdot \mathrm{d}^{-1}$ of body mass $(P<0.001)$ without affecting regular dietary protein $(P=0.176)$ or energy intake $(P=0.167)$. Placebo supplementation $(n=15)$ did not affect regular dietary protein intake $(P=0.910)$ but decreased regular dietary energy intake $(P=0.047)$. Regular leucine intake was unevenly 
distributed over the day, but increased by supplementation at breakfast $(P<0.001)$ and dinner $(P=0.010)$ to at least $2.46 \mathrm{~g}$ leucine.meal ${ }^{-1}$, without reducing regular dietary leucine intake $(P=0.103)$. Animal-based protein intake-the main protein source-was not affected by supplementation ( $P=0.358$ ). Personalized protein supplementation ensured an adequate quantity and even distribution of protein and leucine over the day, without affecting regular dietary protein or energy intake.

Keywords: protein, leucine, supplement, sarcopenia, geriatrics, age, energy

\section{INTRODUCTION}

Sarcopenia is the loss of skeletal muscle function and mass through aging $(1,2)$. Exercise is the primary treatment component and improves older adults' muscle strength, muscle mass and physical functioning (2). The combination of exercise with protein supplementation results in even greater gains in lean mass and leg strength compared to exercise alone $(3,4)$. Leucine plays a dual role as regulator of intracellular signaling pathways leading to protein synthesis and as substrate for protein synthesis $(5,6)$. Indeed, sarcopenia has been associated with low protein intake and specific dietary patterns (butter, red meat, gravy and potato) $(7,8)$. An umbrella review recommends supplementation of leucine for older adults with sarcopenia to improve muscle mass (4).

Although it is clear that protein supplementation is of importance in the treatment of sarcopenia, multiple variables of protein supplementation (quantity, quality, and distribution) must be considered. First, the muscle protein synthesis (MPS) in response to exercise and protein intake is blunted in older adults compared to younger individuals (9). As a result, the Recommended Dietary Allowance (RDA) for protein for adults $\left(0.8 \mathrm{~g} \cdot \mathrm{kg}^{-1} \cdot \mathrm{d}^{-1}\right.$ of body mass) is insufficient for older adults (10-14). Therefore, expert groups and guidelines recommend a protein intake of $1.0 \mathrm{~g} \cdot \mathrm{kg}^{-1} \cdot \mathrm{d}^{-1}$ of body mass for older adults and up to $1.5 \mathrm{~g} \cdot \mathrm{kg}^{-1} \cdot \mathrm{d}^{-1}$ of body mass in case of acute or chronic diseases (15-17). Second, the protein quality is relevant for sufficient anabolic stimulation of MPS (16). Protein quality is determined by the protein source (plant- or animal-based) that influences the digestibility and the amino-acid composition (e.g., essential amino-acids such as leucine). Third, an even protein distribution over the day is recommended. More specifically, the PROT-AGE group recommends for healthy older adults $25 \mathrm{~g}$ protein per meal, of which $2.5-2.8 \mathrm{~g}$ of leucine. This equal distribution needs to ensure sufficient protein intake throughout the day to maximize stimulation of MPS (16).

Recent studies have described regular dietary protein intake and its distribution over the day in sarcopenic older adults $(18,19)$. However, we are not aware of studies that have described the intake of leucine and its distribution over the day in this population.

Abbreviations: BMI, body mass index; EDR, estimated dietary records; ENHANce, exercise and nutrition for healthy aging; EWGSOP, European working group on sarcopenia in older people; MNA-SF, Mini nutritional assessment-short form; MPS, muscle protein synthesis; RDA, recommended dietary allowance; SMI, Skeletal muscle index; Wk 12, week twelve; WHO, World health organization.
The first aim of this study is to assess the intake and distribution of regular dietary protein (primary outcome) and leucine, the protein source and energy intake in (pre)sarcopenic community-dwelling older adults. The supplementation of participants with protein supplements may affect regular dietary intake. In that regard, our second aim was to assess if personalized protein supplementation could ensure an adequate protein intake in older adults with (pre)sarcopenia and if this supplementation affected the dietary protein, leucine or energy intake.

We hypothesized that (pre)sarcopenic community-dwelling older adults do not reach the recommended dietary protein intake through their regular dietary intake. Also, we hypothesize that that through personalized protein supplementation the recommendation of $1.5 \mathrm{~g} \cdot \mathrm{kg}^{-1} \cdot \mathrm{d}^{-1}$ of body mass can be reached without affecting regular dietary protein or energy intake.

\section{METHODS \\ Study Design}

A preliminary feasibility study in participants of the ongoing Exercise and Nutrition for Healthy AgeiNg (ENHANce) study was performed with participants included in a period between February 2018 and August 2019. The food diaries of (pre)sarcopenic participants that were screened for the ENHANce study were included in the analysis to describe regular protein intake $(n=51)$. For analysis of the effect of the protein supplement on regular dietary intake, participants were divided in two groups: the protein supplement group ( $\operatorname{arm} 2,3$, and 4 of ENHANce) or the placebo supplement group (arm 1 and 5 of ENHANce). In total, $n=35$ ENHANce participants initiated and completed the ENHANce intervention period as well as a second food diary after 12 weeks of the ENHANce study. These participants were included in the analyses to describe the effect of personalized supplementation on regular protein intake.

The ENHANce study is an ongoing, single-center, placebocontrolled triple blinded randomized controlled trial, that was initiated in February 2018. Details of the methods are described elsewhere (20). In brief, the ENHANce study aims to examine the effect of combined anabolic interventions (exercise and food compounds) on physical functioning in (pre)sarcopenic older adults. The ENHANce study consists of a screening visit (1 month before the start of intervention) and a 12week intervention period. During the screening visit, fulfillment with the inclusion criteria was checked, participants were asked to complete a food diary during the first week after screening and participants were block randomized (based on 
gender) into one of the five intervention arms: (1) Exercise intervention + protein placebo + PUFA's placebo; $(2)$ Protein + PUFA's placebo; (3) Exercise intervention + protein + PUFA's placebo; (4) Exercise intervention + protein + PUFA's; (5) Control group: protein placebo + PUFA's placebo. The 12week intervention period started and ended with an extensive visit including measurements of physical and cognitive abilities (Supplementary Figure 1). The study was approved by KU Leuven/UZ Leuven Ethics Committee (s60763) and registered on ClinicalTrials.gov (NCT03649698).

\section{Study Population and Inclusion Criteria}

Participants of present study are community-dwelling older adults (aged $\geq 65$ years) living in Belgium. Participants were recruited from Leuven and surrounding area in a number of different ways, including senior citizen organizations, as described in the study protocol (20). The ENHANce participants screened between February 2018 and July 2019 had "presarcopenia," "sarcopenia," or "severe sarcopenia" (in this article also referred to as "sarcopenia") according to the operational definition of the European Working Group on Sarcopenia in Older People (EWGSOP1) (1). From November 2018 onwards, participants had "probable sarcopenia," "confirmed sarcopenia," or "severe sarcopenia" (in this article referred to as "sarcopenia") according to EWGSOP2 (2). The period between November 2018 and July 2019 was a transition period where both definitions were accepted. Other inclusion criteria were: to be able to communicate in Dutch, English or French, no allergy to milk, soy, peanut or peanut oil, Mini-Mental State Examination (MMSE) > 21 (21), no terminal illness with a prognosis $<6$ months, protein intake lower than $1.5 \mathrm{~g} \cdot \mathrm{kg}^{-1} \cdot \mathrm{d}^{-1}$ of body mass 1 week after screening, not following a training program equal to or more than twice per week during the last 6 months, no uncontrolled disease or acute cardiovascular problems (no medical contraindication to perform physical activities), glomerular filtration rate $>$ $30 \mathrm{ml} \cdot \mathrm{min}^{-1} \cdot\left(1.73 \mathrm{~m}^{2}\right)^{-1}$, fasting glycaemia $<126 \mathrm{mg} \cdot \mathrm{dl}^{-1}$ and no treatment for diabetes and no impairments or diseases that impose problems to study participation according to the investigators. Written informed consent was obtained by the participant before the start of the screening visit.

\section{Physical Assessment and Sarcopenia Assessment}

Participant characteristics including age (years), body mass index (BMI, $\mathrm{kg} / \mathrm{m}^{2}$ ), and risk of malnutrition were assessed. Body weight (SECA, model no 8801321009, SECA UK Ltd.) to the nearest $0.1 \mathrm{~kg}$ and height (Harpenden stadiometer, Holtain Ltd., Crosswell, UK) to the nearest $0.1 \mathrm{~cm}$, were measured standing upright, barefoot and in light clothing. The BMI was calculated as weight $/$ height $^{2}$. The Mini Nutritional AssessmentShort Form (MNA-SF) was completed, classifying participants in a range between 0 and 14 points. A score of $0-7$ indicates malnourishment and a score of 8-11 identifies persons at risk of malnutrition (22).

Appendicular lean mass was assessed by dual-energy X-ray absorptiometry (DXA, Horizon A scanner, Hologic Inc., Bedford,
MA, USA). Low muscle mass was defined by the skeletal muscle index (SMI), which is the appendicular lean mass $(\mathrm{kg})$ divided by height ${ }^{2}\left(\mathrm{~m}^{2}\right)$. Participants with presarcopenia and sarcopenia (EWGSOP1) and confirmed or severe sarcopenia (EWGSOP2) had low muscle mass. The cut-off of low SMI in EWGSOP1 was SMI $<7.26 \mathrm{~kg} / \mathrm{m}^{2}$ for men and SMI $<5.50 \mathrm{~kg} / \mathrm{m}^{2}$ for women (1) and in EWGSOP2, the cut-off was SMI $<7.00 \mathrm{~kg} / \mathrm{m}^{2}$ for men and SMI $<5.50 \mathrm{~kg} / \mathrm{m}^{2}$ for women (2).

Handgrip strength was measured by hand dynamometry (Jamar 1, TEC Inc., Clifton, NJ, USA) while the participant was seated with the elbow at a $90^{\circ}$ angle according the American Society of Hand Therapists (23) for EWGSOP1 measurements. The mean value of three consecutive measurements of the dominant hand [according to Fried et al. (24)] was recorded for scoring purposes. According to the EWGSOP1 criteria, the cut-off values were dependent of the BMI (1). The EWGSOP2 proposed the Southampton protocol to assess handgrip strength six times, alternating sides and the maximal value was reported (25). According to the EWGSOP2, low grip strength was defined as $<16 \mathrm{~kg}$ for women and $<27 \mathrm{~kg}$ for men according to the EWGSOP2 (2).

Gait speed was assessed over a distance of six meters. Participants were instructed to walk $6 \mathrm{~m}$ on usual pace (walking aids allowed). The time was measured over $4 \mathrm{~m}$ : from the moment the participant's foot passed the mark of the $1 \mathrm{~m}$ line on the ground until the foot passed the mark of the $5 \mathrm{~m}$ line, according to the BC guidelines (26). The mean of three tests was calculated for scoring purposes. A cut-off of $\leq 0.8 \mathrm{~m} \cdot \mathrm{s}^{-1}$ was used to define low gait speed according to the definition of the EWGSOP (1) and EWGSOP2 (2).

The chair stand test was performed by measuring the time required to rise five consecutive times as quickly as possible from a chair with arms folded in front of the chest (27). The cutoff point for low physical performance was $>15 \mathrm{~s}$, as defined according to the EWGSOP2 (2).

\section{Estimated Dietary Records}

Participants completed a 4-day estimated dietary records (EDR) on non-consecutive days including 3 week- and 1 weekend day. Based on the formula of Beaton (28) including the withinsubject standard deviation of older (65-85 years) adults living in the north of England (29), a 4-day EDR is appropriate to assess protein intake of an individual. Non-consecutive days and alternating periods were chosen to obtain a better estimate of the day-to-day variability (30). At screening, recorded days were Monday, Wednesday, Friday, Sunday, and at week 12, recorded days were Tuesday, Thursday, Saturday, and Monday. Participants were instructed to meticulously record food and beverage intake for $24 \mathrm{~h}$. Portion sizes were documented in predefined household units and determined based on "Maten en Gewichten," a guide to convert qualitative data relating to the amount (estimates) of food ingested into quantitative data in a uniform manner (31). Time of day, description of food and brand of food were documented in the EDR. Quality of records was assured by reviewing records together with the participant in order to complete the records as accurately as possible. 


\section{Assessment of Dietary Intake}

Dietary intake was computed based on the Belgian and USA Food Composition Table [Nubel, BE (31) and USDA FoodData Central, USA] (32). The estimate of mean protein $\left(\mathrm{g} \cdot \mathrm{kg}^{-1} \cdot \mathrm{d}^{-1}\right.$ of body mass, $\mathrm{g} \cdot \mathrm{day}^{-1}$ or $\%$ of total energy $\cdot \mathrm{day}^{-1}$ ), fat ( $\%$ of total energy $\cdot$ day $^{-1}$ ), carbohydrates ( $\%$ of total energy $\cdot$ day $^{-1}$ ), energy $\left(\mathrm{kcal} \cdot \mathrm{kg}^{-1} \cdot \mathrm{d}^{-1}\right.$ of body mass or $\left.\mathrm{kcal} \cdot \mathrm{day}^{-1}\right)$, leucine $\left(\mathrm{g} \cdot \mathrm{day}^{-1}\right.$ or $\mathrm{mg} \cdot \mathrm{kg}^{-1} \cdot \mathrm{d}^{-1}$ of body mass) consumption was calculated as a mean of 4 days. The actual body weight of the participant was used. Snacks were defined as the eating moments between meals. Snack 1 is defined as snacks between breakfast and lunch, snack 2 between lunch and dinner and snack 3 after dinner, before bedtime. Factors of protein quality included the protein source and amino-acids composition, such as leucine. The protein source (plant/animal source) of each dietary protein product was based on the Dutch Food Composition Database (33). Amino-acid composition was based on the USDA food composition database (USDA FoodData Central) (32). The amino-acid composition of a food item was analyzed when the relative protein contribution of this product was $1 \%$ or more of the total protein intake per day. Regular dietary intake reflects the protein intake originating from foods while the total intake reflects the dietary intake and the intake from supplements.

\section{Calculation of Protein Supplementation}

The aim of the personalized supplementation was to reach the before mentioned protein recommendation for older adults with acute or chronic diseases of $1.5 \mathrm{~g} \cdot \mathrm{kg}^{-1} \cdot \mathrm{d}^{-1}$ of body mass (16). Meals were not substituted with a supplement, but a supplement was added to a meal if necessary. The exact amount (to the nearest $0.1 \mathrm{~g} \cdot \mathrm{kg}^{-1} \cdot \mathrm{d}^{-1}$ of body mass) of protein needed to reach this recommendation was calculated. Each meal, if needed, was supplemented according to the following rule: a combined (diet + supplement) protein intake of at least $25 \mathrm{~g}$ protein/meal (breakfast/lunch/dinner) must be reached. Next, in case the protein intake of $1.5 \mathrm{~g} \cdot \mathrm{kg}^{-1} \cdot \mathrm{d}^{-1}$ of body mass intake per day was not yet reached, the combined (diet + supplement) protein intake per meal was equally increased over the meals (breakfast/lunch/dinner) up to a maximum of $35 \mathrm{~g}$ protein $\cdot \mathrm{meal}^{-1}$, but a maximum of $700 \mathrm{kcal} \cdot \mathrm{meal}^{-1}$ is never exceeded [35\% of average requirement for energy intake for older adults (34)]. In case the protein intake of 1.5 $\mathrm{g} \cdot \mathrm{kg}^{-1} \cdot \mathrm{d}^{-1}$ of body mass was not yet reached after applying the above rules, the snack before bedtime (snack 3) was supplemented. In summary, if supplementation was needed, at least one evening snack and maximum three main meals and the evening snack were enriched. For supplementation calculations, the body weight of participants with a BMI $<22$ or $>27$ $\mathrm{kg} / \mathrm{m}^{2}$ was adjusted: the adjusted body weight of participant with BMI $<22$ was the body weight that would result in a BMI of $22 \mathrm{~kg} / \mathrm{m}^{2}$, the adjusted body weight of participant with BMI $>27$ was the body weight that would result in a BMI of $27 \mathrm{~kg} / \mathrm{m}^{2}$ (35). The supplemented protein (g) was visualized for each individual receiving the protein supplement in Supplementary Figure 2.

\section{Participant Instructions for Supplement Intake}

Participants were instructed to initiate the intake of the powder supplement (with protein or placebo powder) 5 days before the start of the 12-week intervention period. Participants received instructions on how to dissolve the protein powder and suggestions of drinks and foods to mix with the powder before consumption. For that purpose, each participant received an individualized drinking glass for each meal or snack that had to be supplemented. By means of a line on this drinking glass, the amount of powder to be taken with this meal/snack was indicated. For each meal/snack at home, the participant completed the glass for that meal/snack up to the marked line with the provided powder. Participants in the protein supplement group received Resource Instant Protein (Nestlé, 4.5 g protein per $5 \mathrm{~g}$ powder, $9.14 \%$ leucine). The placebo product was Resource dextrin maltose (Nestlé, $0 \mathrm{~g}$ protein). Nutritional content of both powders is described in Supplementary Table 1. The powder boxes and drinking glasses were prepared by an unblinded researcher, who did not participate in study visits or had contact with the participants. The boxes for protein or placebo powder products were equal looking blank boxes.

\section{Assessment of Compliance}

Compliance with powder supplement intake was assessed by weighing the amount of powder that was taken from the provided powder box at each study visit (seven times in 12-week period). The compliance was defined as the proportion of amount of powder that was actually removed from the boxes to the prescribed amount of powder that was suggested to be taken.

\section{Statistics}

\section{Sample Size}

The data reporting in the current study is compliant with the STROBE-nut guidelines (36). As mentioned in the methods section, these analyses are based on data from the ongoing ENHANce study. Although the ENHANce study is primarily powered on functional outcomes, the number of participants needed to detect a difference of $0.5 \mathrm{~g} \cdot \mathrm{kg}^{-1} \cdot \mathrm{d}^{-1}$ of body mass with a standard deviation of 0.22 , two time points and an assumed correlation of 0.9 , is three participants per group with a power of 0.80 with alpha level of 0.05 . Therefore, these analyses are sufficiently powered to detect differences between the different time points (visits). Post-hoc power analyses are therefore not useful.

\section{Statistical Analyses}

Data analyses were performed using IBM SPSS Statistical package (IBM Corp. Released 2017 IBM SPSS Statistics for Windows, Version 25.0, Armonk, NY). Normal continuous variables are presented as the mean and standard deviation (SD), while the non-normal continuous variables are presented as the median with interquartile ranges (IQR). Normality of variables was checked using a Shapiro-Wilk test. To compare differences in normal distributed variables between regular dietary intake at screening or wk 12 or total intake at wk 12, repeated measures 


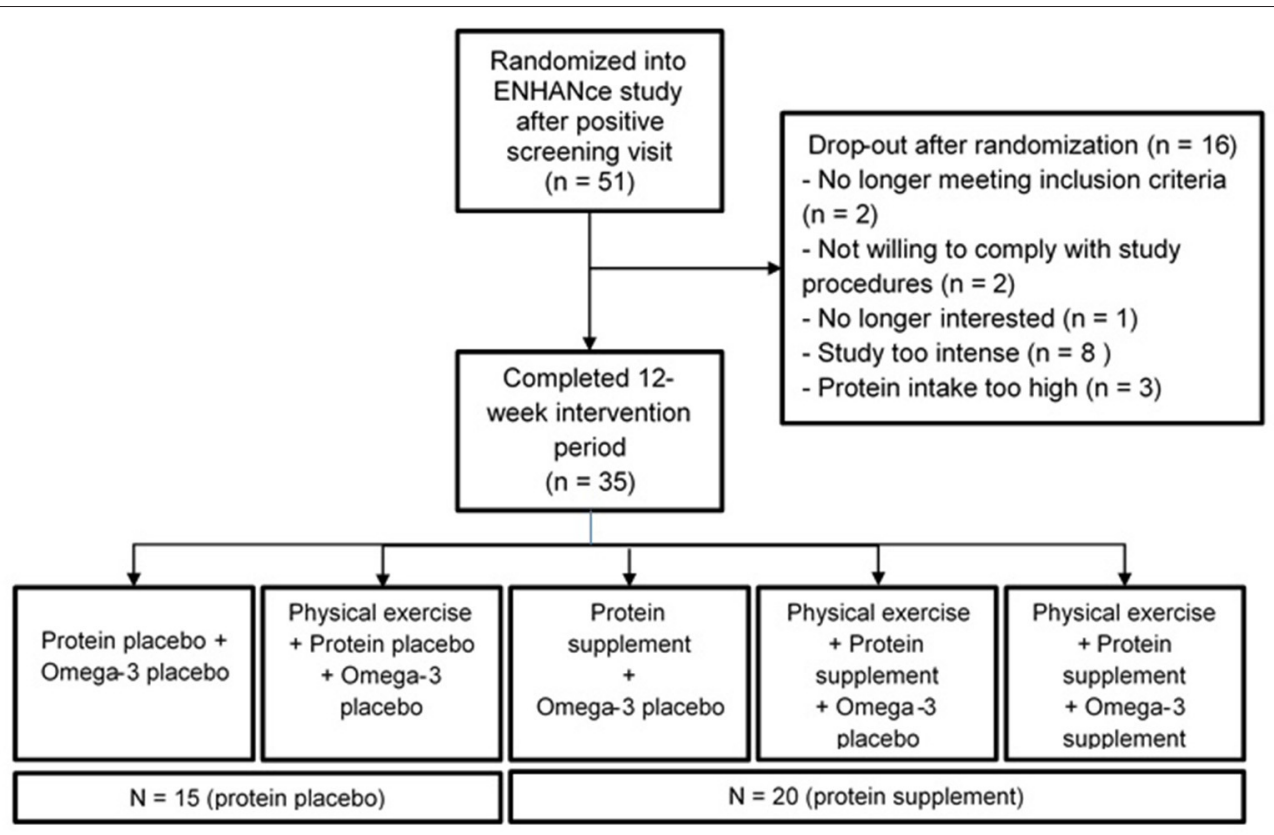

FIGURE 1 | Overview of flow of participant of the ENHANce study relevant for this article.

ANOVA with post-hoc paired sample $t$-test were used. For nonnormal distributed variables were Friedman test (non-parametric alternative to the repeated measures ANOVA) with post-hoc Wilcoxon signed-rank tests used. For comparisons of variables between regular dietary intake at screening or wk 12, the paired $t$-test or Wilcoxon signed-rank test was used depending on distribution. A $p$-value of $<0.05$ (two-tailed) was considered statistically significant.

\section{RESULTS}

\section{Participant Characteristics}

Fifty-one participants in the ENHANce study completed the screening visit and EDR at screening. Thirty-five participants completing EDR at wk 12 since 16 participants dropped out before completion of the 12 -week study period. Fifty percent ( $n=8)$ of the dropouts perceived the study as "too intense," $19 \%(n=3)$ had a protein intake above $1.5 \mathrm{~g} \mathrm{~g} \cdot \mathrm{kg}^{-1} \cdot \mathrm{d}^{-1}$ of body mass, two participants were no longer meeting inclusion criteria, two participants were not willing to comply with study procedures, and one participant was no longer interested in study participation. Twenty of the thirty-five participants received a protein supplement, 15 received a placebo supplement (Figure 1). Study participants at screening visit were 73.6 years old $( \pm 6.5)$ and $52.9 \%$ were female. Mean total fat and total carbohydrate intake were, respectively $36.3 \pm 7.6 \%$ of total energy. day ${ }^{-1}$ and $42.5 \pm 9.2 \%$ of total energy.day ${ }^{-1}$ (Table 1). Forty-four participants were included according to EWGSOP1 of which 39 participants were presarcopenic and five participants were sarcopenic; seven participants were according to EWGSOP2, one probable sarcopenic and six confirmed sarcopenic.

\section{Energy Intake}

The mean regular dietary energy intake at screening was $2,000 \mathrm{kcal} \cdot \mathrm{day}^{-1}$, or $29.3 \mathrm{kcal} \cdot \mathrm{kg}^{-1} \cdot \mathrm{d}^{-1}$ of body mass ( $n$ $=51$ ). In the protein supplement group, supplementation significantly increased the total energy intake $\left(2,110 \mathrm{kcal} \cdot\right.$ day $^{-1}$, $30.4 \mathrm{kcal} \cdot \mathrm{kg}^{-1} \cdot \mathrm{d}^{-1}$ of body mass) compared to the regular dietary intake at wk $12\left(1,990 \mathrm{kcal} \cdot \mathrm{day}^{-1}, 28.9 \mathrm{kcal} \cdot \mathrm{kg}^{-1} \cdot \mathrm{d}^{-1}\right.$ of body mass). In the placebo supplement group, regular dietary energy intake $\left(\mathrm{kcal}^{-\mathrm{day}^{-1}}{ }^{-1}\right.$ did not significantly change, except that the regular dietary intake decreased from screening (29.1 $\mathrm{kcal} \cdot \mathrm{kg}^{-1} \cdot \mathrm{d}^{-1}$ of body mass $)$ to wk $12\left(26.3 \mathrm{kcal} \cdot \mathrm{kg}^{-1} \cdot \mathrm{d}^{-1}\right.$ of body mass; $p=0.047$; Table 2 ).

\section{Protein Quantity}

The mean regular dietary protein intake at screening was 72.8 $\pm 17.6 \mathrm{~g} \cdot \mathrm{day}^{-1}$, or $1.06 \pm 0.3 \mathrm{~g} \cdot \mathrm{kg}^{-1} \cdot \mathrm{d}^{-1}$ of body mass $(n$ $=51)$. Participants receiving a protein supplement $(n=20)$ showed an increased total protein intake $\left(105 \mathrm{~g} \cdot \mathrm{day}^{-1}, 1.55 \pm\right.$ $0.3 \mathrm{~g} \cdot \mathrm{kg}^{-1} \cdot \mathrm{d}^{-1}$ of body mass) compared to regular dietary intake at screening (69.1 g.day ${ }^{-1}, 1.04 \pm 0.2 \mathrm{~g} \cdot \mathrm{kg}^{-1} \cdot \mathrm{d}^{-1}$ of body mass) or wk 12 (74.7 $\mathrm{g} \cdot \mathrm{day}^{-1}, 1.13 \pm 0.4 \mathrm{~g} \cdot \mathrm{kg}^{-1} \cdot \mathrm{d}^{-1}$ of body mass), whilst participants receiving a placebo supplement $(n=15)$ did not significantly change regular dietary protein intake $\left(\mathrm{g} \cdot \mathrm{d}^{-1}\right.$ or $\mathrm{g} \cdot \mathrm{kg}^{-1} \cdot \mathrm{d}^{-1}$ of body mass). Compared to regular dietary intake at screening (15.8 energy\%) or wk 12 (15.8 energy\%), protein supplementation resulted in an increased total relative protein intake (20.9 energy\%; Table 3).

At screening, the regular dietary distribution of protein intake at breakfast, lunch, dinner, and snack times was unequal, and breakfast did not meet the $25 \mathrm{~g}$ protein per meal threshold $(n=$ 51, Supplementary Table 2). Protein supplementation resulted in higher total protein intake $(28.2 \mathrm{~g}$ at breakfast $p<0.001$; $36.7 \mathrm{~g}$ at dinner, $p=0.004$ ) compared to regular dietary intake 
TABLE 1 | Characteristics (mean \pm SD) of community-dwelling (pre)sarcopenic older adults at start of the intervention period.

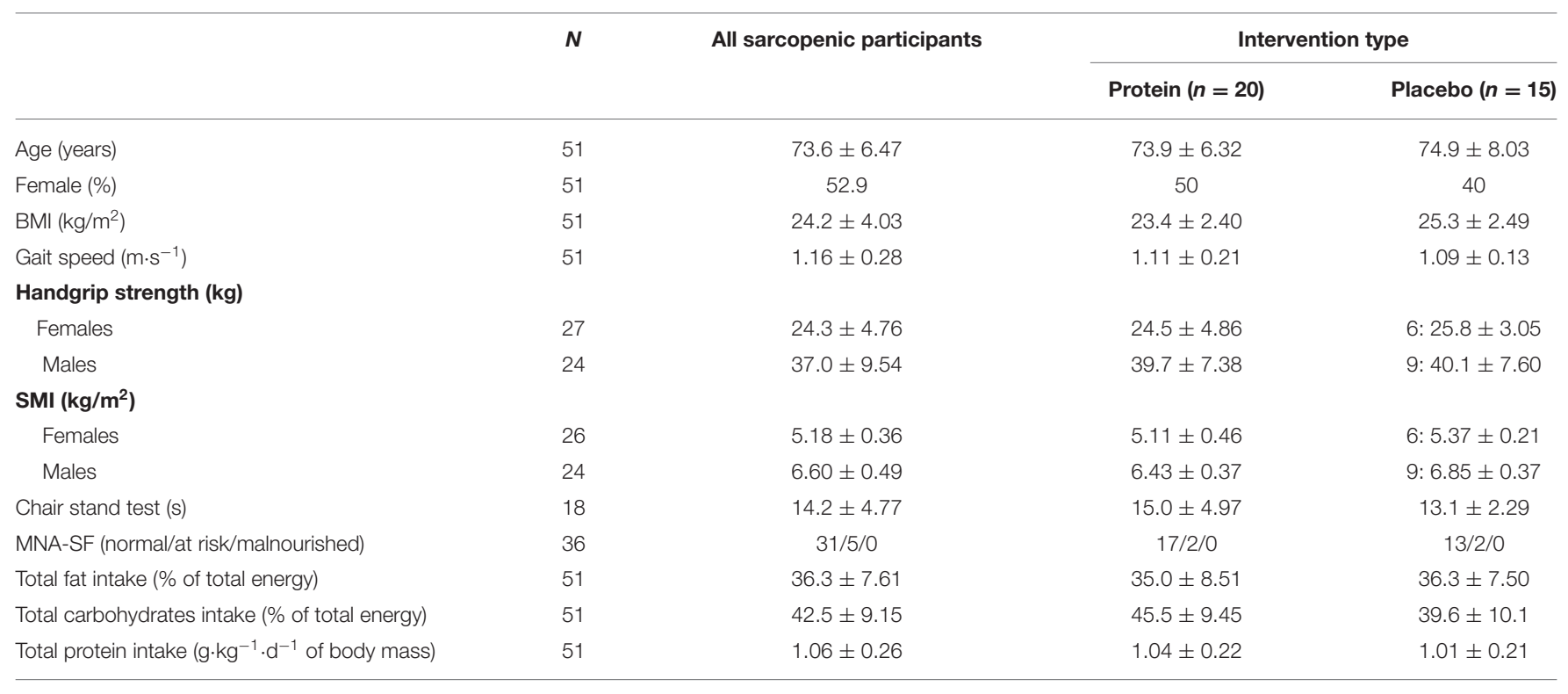

Values presented as mean $\pm S D . N$, number of included subjects; BMI, body mass index; SMI, skeletal muscle index; MNA-SF, mini nutritional assessment-short form.

TABLE 2 | Energy intake (median and IQR) based on the 4-day EDR of subgroup of community-dwelling (pre)sarcopenic older adults receiving protein supplement ( $n=$ 20) or placebo supplement $(n=15)$.

\begin{tabular}{|c|c|c|c|c|c|}
\hline & Energy & Dietary intake, screening & Dietary intake, wk 12 & Total intake, wk 12 & $P$-value \\
\hline $\begin{array}{l}\text { All sarcopenic } \\
\text { participants }(n=51)\end{array}$ & $\mathrm{kcal} \cdot \mathrm{d}^{-1}$ & $2,000 \pm 414$ & & & \\
\hline Protein $(n=20)$ & $\mathrm{kcal} \cdot \mathrm{d}^{-1}$ & $1,830(1,660-2,000)$ & $1,990(1,600-2,170)$ & $2,110(1,780-2,320)$ & $\begin{array}{l}0.067\left(D_{s} \text { vs. } T_{w k 12}\right) ; \\
0.502\left(D_{w k 12} \text { vs. } D_{s}\right) ; \\
<\mathbf{0 . 0 0 1 *}^{*}\left(D_{w k 12} \text { vs. } T_{w k 12}\right)\end{array}$ \\
\hline \multirow[t]{2}{*}{ Placebo $(n=15)$} & $\mathrm{kcal} \cdot \mathrm{d}^{-1}$ & $2,000 \pm 326$ & $2,020 \pm 434$ & & $0.873\left(D_{s}\right.$ vs. $\left.D_{w k 12}\right)$ \\
\hline & $\begin{array}{l}\mathrm{kcal} \cdot \mathrm{kg}^{-1} \cdot \mathrm{d}^{-1} \text { of body } \\
\text { mass }\end{array}$ & $29.1(26.5-65.7)$ & $26.28(23.0-31.7)$ & & 0.047 ( $D_{s}$ vs. $\left.D_{w k 12}\right)$ \\
\hline
\end{tabular}

$D_{s}$, dietary intake, screening. $D_{w k 12}$, dietary intake, wk 12. $T_{w k 12}$, total intake at week 12. P-value repeated measures ANOVA between visits, dietary intake $\left(k c a l \cdot d^{-1}\right): 0.001^{*}$, dietary intake ( $\mathrm{kcal} \cdot \mathrm{kg}^{-1} \cdot \mathrm{d}^{-1}$ of body mass): $0.004^{*}$.

Bold $p$-values represent statistically significant results $(p<0.05)$.

at screening and wk 12 at breakfast $(11.7 \mathrm{~g}, p<0.001 ; 10.2 \mathrm{~g}$, $p<0.001)$ and dinner (24.4 g, $p=0.002 ; 26.2 \mathrm{~g}, p=0.001)$. Dietary protein intake after dinner/before bedtime (snack 3 ) decreased ( $p=0.023$ ) at wk 12 compared to screening (Figure 2; Supplementary Table 2).

\section{Protein Quality}

The contribution of animal- and plant-based sources to daily protein intake was not significantly different between regular dietary intake at screening (animal 63.5\%; plant 36.5\%) and wk 12 (animal 61.9\%, plant 38.1\%; $p=0.358$ ). The daily intake of the individual amino acids ( $g$ ) did not significantly change between regular dietary intake at screening and wk 12, except a slight increase in cysteine intake (Supplementary Table 3). Daily dietary leucine intake at screening $\left(6.1 \pm 1.0 \mathrm{~g} \cdot \mathrm{day}^{-1}\right.$, $114 \pm 57 \mathrm{mg} \cdot \mathrm{kg}^{-1} \cdot \mathrm{d}^{-1}$ of body mass $)$ or wk $12(6.8 \pm 1.6$ $\mathrm{g} \cdot \mathrm{day}^{-1}, 102 \pm 30 \mathrm{mg} \cdot \mathrm{kg}^{-1} \cdot \mathrm{d}^{-1}$ of body mass) increased by supplementation $\left(9.5 \pm 2.2 \mathrm{~g} \cdot \mathrm{day}^{-1}, 140 \pm 24 \mathrm{mg} \cdot \mathrm{kg}^{-1} \cdot \mathrm{d}^{-1}\right.$ of body mass), without affecting regular dietary leucine intake (Table 4).

At screening, the regular dietary distribution of leucine intake at breakfast, lunch, dinner and snack times was unequal, and no meal reached the $2.5 \mathrm{~g}$ leucine threshold (Table 4). Protein supplementation resulted in higher total leucine intake $(2.46 \mathrm{~g}$ at 
TABLE 3 | Protein intake (mean \pm SD) based on the four-day EDR of all community-dwelling (pre)sarcopenic older adults and subgroups of $n=20$ receiving protein supplement and $n=15$ receiving placebo supplements.

\begin{tabular}{|c|c|c|c|c|c|}
\hline & Protein & Dietary intake, screening & Dietary intake, wk 12 & Total intake, wk 12 & $P$-value \\
\hline \multirow{2}{*}{$\begin{array}{l}\text { All sarcopenic } \\
\text { participants }(n=51)\end{array}$} & $\mathbf{g} \cdot \mathbf{d}^{-1}$ & $72.8 \pm 17.6$ & & & \\
\hline & $\mathrm{g} \cdot \mathrm{kg}^{-1} \cdot \mathrm{d}^{-1}$ of body mass & $1.06 \pm 0.26$ & & & \\
\hline \multirow[t]{3}{*}{ Protein $(n=20)$} & $g \cdot d^{-1}$ & $69.1 \pm 10.7$ & $74.7 \pm 18.5$ & $104.7 \pm 22.0$ & $\begin{array}{l}\mathbf{< 0 . 0 0 1}^{\star}\left(D_{s} \text { vs. } T_{w k 12}\right) \\
0.149\left(D_{w k 12} \text { vs. } D_{s}\right) \\
<\mathbf{0 . 0 0 1}^{*}\left(D_{w k 12} \text { vs. } T_{w k 12}\right)\end{array}$ \\
\hline & $\mathrm{g} \cdot \mathrm{kg}^{-1} \cdot \mathrm{d}^{-1}$ of body mass & $1.04 \pm 0.22$ & $1.13 \pm 0.36$ & $1.55 \pm 0.26$ & $\begin{array}{l}<\mathbf{0 . 0 0 1}^{*}\left(D_{s} \text { vs. } T_{w k 12}\right) \\
0.176\left(D_{w k 12} \text { vs. } D_{s}\right) \\
<\mathbf{0 . 0 0 1}^{*}\left(D_{w k 12} \text { vs. } T_{w k 12}\right)\end{array}$ \\
\hline & $\%$ of total energy & $15.5 \pm 2.98$ & $15.8 \pm 2.59$ & $19.4 \pm 3.30$ & $\begin{array}{l}<\mathbf{0 . 0 0 1}^{*}\left(D_{s} \text { vs. } T_{w k 12}\right) \\
0.625\left(D_{w k 12} \text { vs. } D_{s}\right) \\
<\mathbf{0 . 0 0 1}{ }^{*}\left(D_{w k 12} \text { vs. } T_{w k 12}\right)\end{array}$ \\
\hline \multirow[t]{2}{*}{ Placebo $(n=15)$} & $g \cdot d^{-1}$ & $73.8 \pm 18.6$ & $74.9 \pm 15.1$ & & $0.862\left(D_{s}\right.$ vs. $\left.D_{w k 12}\right)$ \\
\hline & $\mathrm{g} \cdot \mathrm{kg}^{-1} \cdot \mathrm{d}^{-1}$ of body mass & $1.00(0.80-1.20)$ & $1.02(0.87-1.17)$ & & $0.910\left(D_{s}\right.$ vs. $\left.D_{w k 12}\right)$ \\
\hline
\end{tabular}

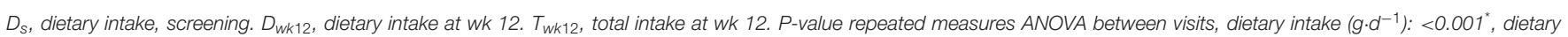
intake ( $\mathrm{kcal} \cdot \mathrm{kg}^{-1} \cdot \mathrm{d}^{-1}$ of body mass): $<0.001^{*}$, dietary intake (\% of total energy): $<0.001^{*}$.

Bold $p$-values represent statistically significant results $(p<0.05)$.

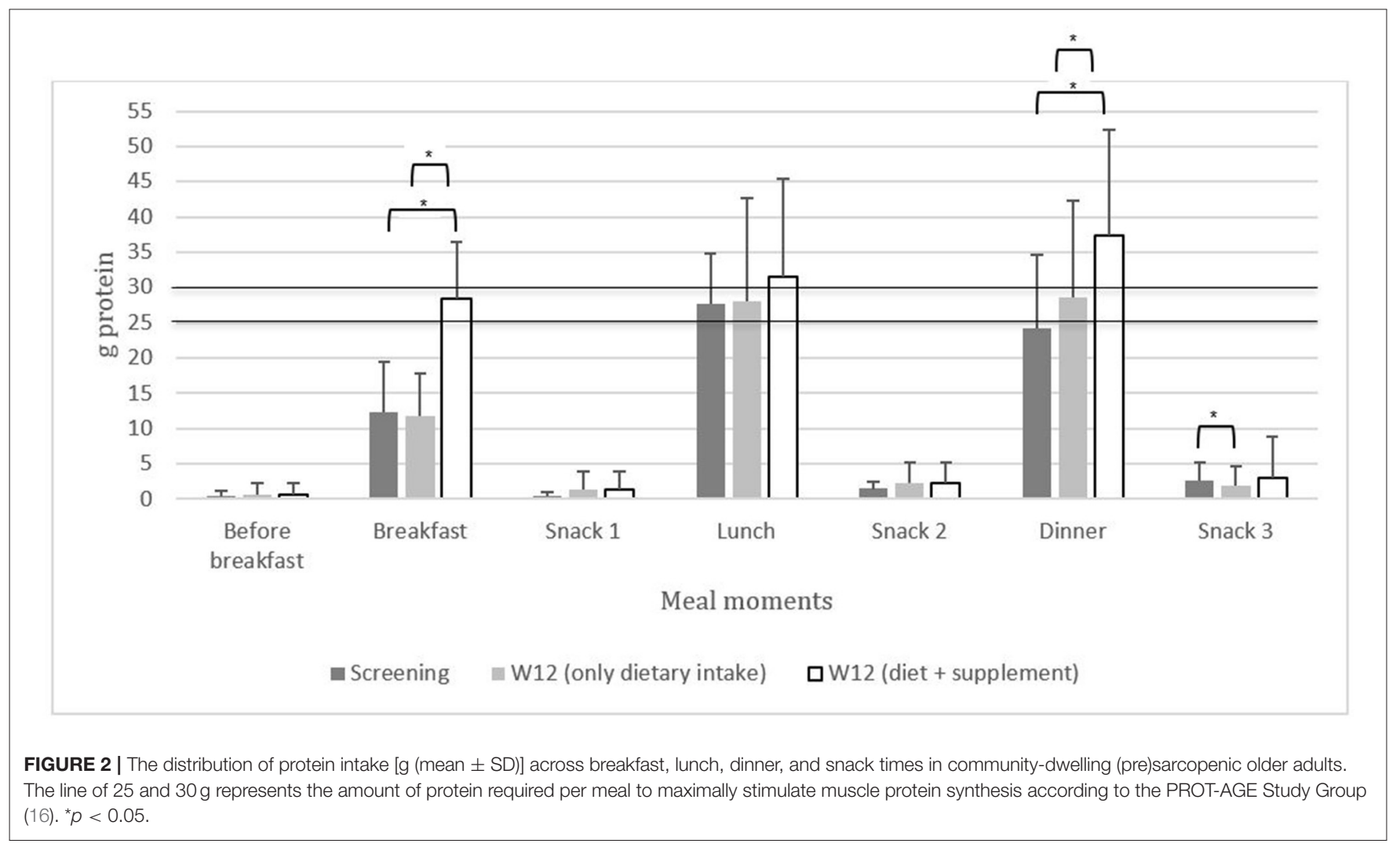

breakfast, $3.33 \mathrm{~g}$ at dinner) compared to regular dietary intake at screening at breakfast $(0.87 \mathrm{~g}, p<0.001)$ and dinner $(1.99 \mathrm{~g}, p=$ 0.009 ) or compared to regular dietary intake at wk 12 at breakfast $(0.90 \mathrm{~g}, p<0.001)$ and dinner $(2.35 \mathrm{~g}, p<0.001$; Table 4$)$.

\section{Compliance}

The compliance with protein powder intake ranged from 44 to $100 \%$, and the compliance with placebo powder intake ranged from 49 to $100 \%$. Seventy-five percent (15/20) of the participants with protein powder supplementation and $79 \%$ (11/14) of the participants with placebo powder supplementation had a compliance higher than $79 \%$. Compliance of one participant of the placebo powder supplementation group was not calculated as this person did not bring the boxes to the study visits. Figure 3 visualizes the compliance on an individual level. 
TABLE 4 | Leucine intake $\left(\mathrm{g} \cdot \mathrm{d}^{-1}\right.$ ) or $\left(\mathrm{mg} \cdot \mathrm{kg}^{-1} \cdot \mathrm{d}^{-1}\right.$ of body mass) mean $\pm \mathrm{SD}$ and distribution of leucine intake (median and interquartile range) of a subgroup of 20 community-dwelling (pre)sarcopenic older adults receiving protein supplement $(n=20)$.

\begin{tabular}{|c|c|c|c|c|c|c|c|}
\hline & $\begin{array}{l}\text { Dietary intake, } \\
\text { screening }\end{array}$ & $\begin{array}{c}\text { Dietary intake, } \\
\text { wk } 12\end{array}$ & $\begin{array}{l}\text { Total intake, } \\
\text { wk } 12\end{array}$ & \multicolumn{3}{|c|}{$P$-value } & \\
\hline$g \cdot d^{-1}$ & $6.07 \pm 0.95$ & $6.75 \pm 1.64$ & $9.50 \pm 2.15$ & \multicolumn{4}{|c|}{$<\mathbf{0 . 0 0 1 *}\left(D_{s}\right.$ vs. $\left.T_{w k 12}\right) ; 0.103\left(D_{w k 12}\right.$ vs. $\left.D_{s}\right) ;<\mathbf{0 . 0 0 1}^{*}\left(D_{w k 12}\right.$ vs. $\left.T_{w k 12}\right)$} \\
\hline \multirow{2}{*}{$\begin{array}{l}\mathrm{mg} \cdot \mathrm{kg}^{-1} \cdot \mathrm{d}^{-1} \text { of body } \\
\text { mass }\end{array}$} & $114 \pm 57.3$ & $102 \pm 30.3$ & $140 \pm 23.8$ & \multicolumn{4}{|c|}{$\mathbf{0 . 0 4 1 *}\left(D_{s}\right.$ vs. $\left.T_{w k 12}\right) ; 0.348$ (Dwk12 vs. $\left.D_{s}\right) ;<\mathbf{0 . 0 0 1 *}\left(D_{w k 12}\right.$ vs. $\left.T_{w k 12}\right)$} \\
\hline & $\begin{array}{c}\text { Before } \\
\text { breakfast }\end{array}$ & Breakfast & Snack 1 & Lunch & Snack 2 & Dinner & Snack 3 \\
\hline $\begin{array}{l}\text { Dietary intake, } \\
\text { screening }\left(g \cdot \text { meal }^{-1}\right)\end{array}$ & $0.00(0.00-0.01)$ & $0.87(0.49-1.09)$ & $0.01(0.00-0.08)$ & $2.34(2.05-2.88)$ & $0.15(0.06-0.22)$ & $1.99(1.17-2.66)$ & $0.21(0.01-0.59)$ \\
\hline $\begin{array}{l}\text { Dietary intake, wk } 12 \\
\left(\mathrm{~g} \cdot \mathrm{meal}^{-1}\right)\end{array}$ & 0.00 (0.00-0.01) & $0.90(0.43-1.40)$ & $0.04(0.00-0.14)$ & 2.55 (1.80-3.08) & $0.14(0.04-0.27)$ & 2.35 (1.22-3.54) & $0.07(0.00-0.51)$ \\
\hline $\begin{array}{l}\text { Total intake, wk } 12 \\
\left(\mathrm{~g} \cdot \mathrm{meal}^{-1}\right)\end{array}$ & $0.00(0.00-0.01)$ & $2.46(1.89-3.24)^{\circ \#}$ & $0.04(0.00-0.14)$ & $2.81(2.30-3.09)$ & $0.14(0.04-0.27)$ & $3.33(2.22-3.89)^{\circ \#}$ & $0.07(0.00-0.57)$ \\
\hline
\end{tabular}

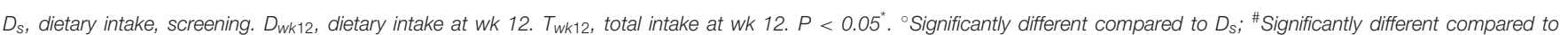

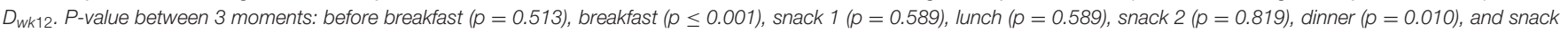
$3(p=0.106)$.

Bold $p$-values represent statistically significant results $(p<0.05)$.
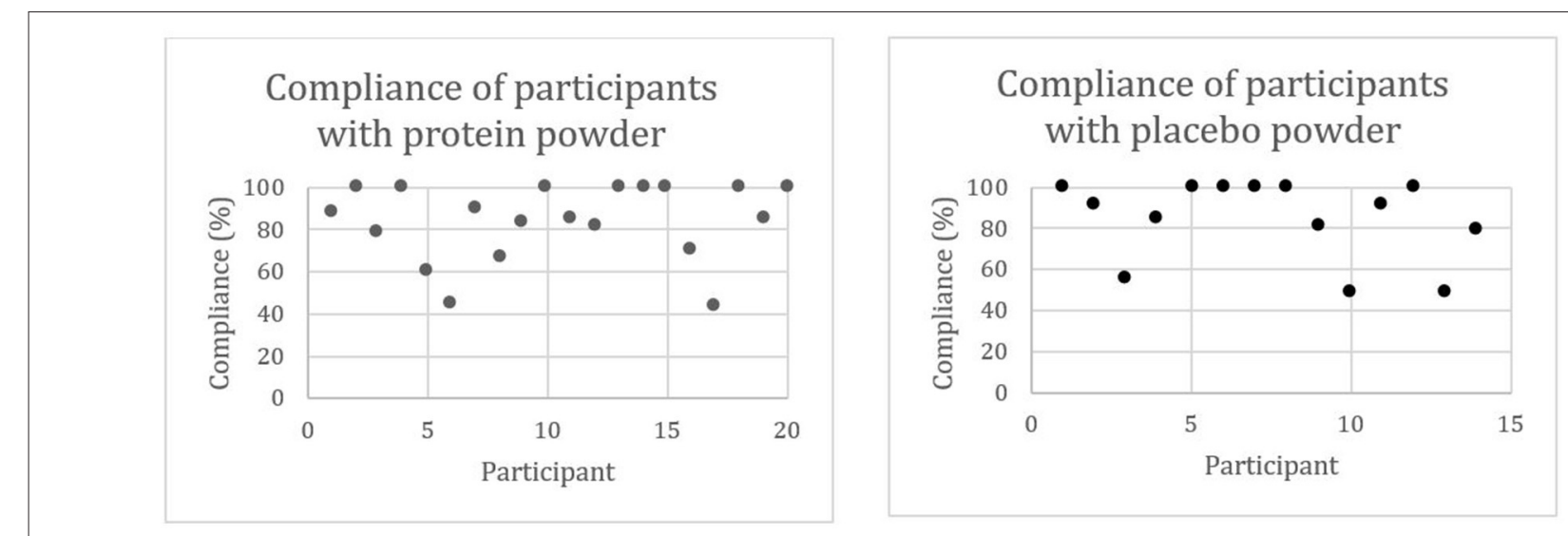

FIGURE 3 | Compliance (\%) of community-dwelling (pre)sarcopenic older adults with protein $(n=20)$ or placebo $(n=15)$ powder intake.

\section{DISCUSSION}

The present study showed that the quantity, quality and distribution of regular dietary protein or leucine intake of community-dwelling (pre)sarcopenic older adults do not reach the recommended levels (16). However, we showed that the addition of a personalized protein supplement resulted in an adequate quantity and quality total protein intake, and a more even distribution over the day, without affecting the protein or energy intake through the diet.

Regular dietary protein intake in Dutch older individuals ranged from $0.78 \pm 0.3 \mathrm{~g} \cdot \mathrm{kg}^{-1} \cdot \mathrm{d}^{-1}$ of body mass in institutionalized older men to $1.11 \pm 0.3 \mathrm{~g} \cdot \mathrm{kg}^{-1} \cdot \mathrm{d}^{-1}$ of body mass in community-dwelling older men (19). Bollwein et al. (18) reported a regular dietary protein intake of 1.07 (0.6-2.3) $\mathrm{g} \cdot \mathrm{kg}^{-1} \cdot \mathrm{d}^{-1}$ of body mass in German community-dwelling older persons (18). Regular dietary protein intake in (pre)sarcopenic community-dwelling older adults described in this study is in line with these previous studies. Discussing this result is not straightforward, as there is no consensus yet on the "optimal" protein intake of older adults. The World Health Organization (WHO) RDA of $0.8 \mathrm{~g} \cdot \mathrm{kg}^{-1} \cdot \mathrm{d}^{-1}$ of body mass is based on 19 nitrogen balance studies, only one of which has been performed in older adults. Moreover, the NB technique is now considered inappropriate for making recommendations $(37,38)$, and is replaced by the indicator amino acid oxidation (IAAO) method. Experiments with this latter technique in older adults ( $>65$ years) resulted in higher RDA values: $1.29 \mathrm{~g} \cdot \mathrm{kg}^{-1} \cdot \mathrm{d}^{-1}$ of body mass for women and $1.24 \mathrm{~g} \cdot \mathrm{kg}^{-1} \cdot \mathrm{d}^{-1}$ of body mass for men $(39,40)$. However, protein intake that aims to reach the RDA, which aims to avoid deficiencies, is not equal to optimizing clinical outcomes. Protein intake in accordance with the RDA may not always lead to optimally stimulated MPS (41). Other studies examined the effect of a protein dose higher than the RDA. First, compared 
to a single dose RDA $\left(0.8 \mathrm{~g} \cdot \mathrm{kg}^{-1} \cdot \mathrm{d}^{-1}\right.$ of body mass $)$, a double dose RDA (1.5 $\mathrm{g} \cdot \mathrm{kg}^{-1} \cdot \mathrm{d}^{-1}$ of body mass) resulted in increased MPS and whole-body lean mass, maintenance of lean mass and less decrease in appendicular lean mass and leg power (42-44). Second, increasing the protein intake from $0.8 \mathrm{~g} \cdot \mathrm{kg}^{-1} \cdot \mathrm{d}^{-1}$ of body mass to $1.2 \mathrm{~g} \cdot \mathrm{kg}^{-1} \cdot \mathrm{d}^{-1}$ of body mass showed only limited effects on MPS (45). Taken together, it is expected, that optimal protein dose for older adults is higher than the current RDA as proposed by the WHO (38).

In our study in (pre)sarcopenic older adults, regular dietary protein intake was unevenly distributed over the day, with the highest protein intake at lunch and the lowest at breakfast. These results are similar to the protein intake distribution in a Dutch community-dwelling, frail or institutionalized population (19) or a German frail population (18). Also in a French older population, protein was mainly consumed at lunch $56.5 \%$ of all proteins) (46). However, in other countries such as Norway, protein intake was highest at dinner in older adults (47). Belgian older adults commonly consume a warm meal for lunch, which is associated with a higher protein intake compared to bread-based meals (19).

The aim of this study was not only to achieve adequate levels of total protein intake per day, but also to achieve an even distribution of 25-30 g protein per meal. Indeed, reviews suggest an optimal MPS with evenly distributed protein of 25$30 \mathrm{~g} \cdot \mathrm{meal}^{-1}(13,16)$, or $30-40 \mathrm{~g} \cdot \mathrm{meal}^{-1}(12)$, or state that there is no practical upper limit to the anabolic response to protein intake in the context of a meal (48). No upper limit is observed when also the rate of protein breakdown is taken into account. Higher protein intake results in greater insulin response with subsequent suppression of protein breakdown and thus a greater anabolic response (48). Protein supplementation could improve the distribution of protein intake in (pre)sarcopenic older adults throughout the different meals.

Regarding the factors that influence protein quality, previous research showed that animal-based proteins stimulate MPS more than plant-based proteins, which is caused by, among others, a higher relative leucine content (49). Our study showed highest contribution of animal proteins to the total protein intake, which is in line with Dutch community-dwelling, frail or institutionalized older adults (65\% from animal origin) (19) and American adults over 71 years of age (61\% from animal origin) (50). Also, our study showed that the leucine intake was approximately $114 \mathrm{mg} \cdot \mathrm{kg}^{-1} \cdot \mathrm{d}^{-1}$ of body mass. This is higher than the assumed optimal $55 \mathrm{mg} \cdot \mathrm{kg}^{-1} \cdot \mathrm{d}^{-1}$ of body mass for healthy adults (51), but lower than in older ( $>70$ years) men $(160 \mathrm{mg})$ and women $(130 \mathrm{mg})$ in the National Health and Nutrition Examination Survey III study (NHANES) (52). Moreover, the distribution of leucine in our study sample was uneven and low at breakfast and dinner. A study in healthy older adults without functional limitations showed a more even distribution $(1.97 \pm 1.31 \mathrm{~g}$ at breakfast, $2.5 \pm 1.27 \mathrm{~g}$ at lunch, and $2.27 \pm 1.26 \mathrm{~g}$ at dinner) (53). After protein supplementation, the leucine intake and distribution, and thus the dietary protein quality, was improved without affecting regular dietary protein or energy intake. To the best of our knowledge is this the first study assessing leucine distribution in (pre)sarcopenic community-dwelling older adults. We also found a slight increase in dietary cysteine intake at wk 12 , however, it is unclear if this difference also is clinically relevant. The WHO defines the total sulfur amino-acid requirement (cysteine and methionine) as $15 \mathrm{mg} / \mathrm{kg} \cdot \mathrm{day}^{-1}$ (54). Our study showed a median sulfur amino-acid intake after supplementation of 3.27 $\mathrm{g} \cdot \mathrm{day}^{-1}$ (cysteine $\left(1.23 \mathrm{~g} \cdot \mathrm{day}^{-1}\right.$ ) and methionine $\left(2.04 \mathrm{~g} \cdot \mathrm{day}^{-1}\right.$ ), which is equal to $54.5 \mathrm{mg} / \mathrm{kg} \cdot \mathrm{day}^{-1}$ for a person weighing $60 \mathrm{~kg}$.

The contribution of protein to the daily energy intake was similar in our study $(15.8 \%)$ as in similar study samples in Germany [15.9\% (18)] and the USA [15.4\% (50)]. Also the total daily energy intake is similar among the participants of our study $\left(1,830 \pm 344 \mathrm{kcal} \cdot \mathrm{day}^{-1}\right)$ compared to prefrail $\left(1,800 \pm 636 \mathrm{kcal} \cdot \mathrm{day}^{-1}\right)$ and robust $\left(1,869 \pm 652 \mathrm{kcal} \cdot \mathrm{day}^{-1}\right)$ community-dwelling older adults of the Health ABC study (55) or women $\left(1,464 \mathrm{kcal} \cdot \mathrm{day}^{-1}\right)$ and men $\left(2,034 \mathrm{kcal} \cdot \mathrm{day}^{-1}\right)$ over 71 years of age in the National Health and Nutrition Examination Survey study (50). Higher intake was reported in Dutch older men in the community (to 2,246 $\pm 573 \mathrm{kcal} \cdot \mathrm{day}^{-1}$ ), and lower intake in Dutch older men in institutions $(1,385 \pm$ $358 \mathrm{kcal} \cdot \mathrm{day}^{-1}$ ) (19). Maintaining energy levels is important since higher energy intake is associated with lower hazard ratios of both all-cause and cardiovascular disease mortality in older adults (56).

The main strength of our study is that the participant's protein supplementation is personalized, in contrast to other studies that supplement a certain fixed amount of protein, for example $20 \mathrm{~g}$ per meal (57). Moreover, this study indicated that 12 weeks supplementing with a personalized powder supplement seems possible in this population, which is not achievable in all types of populations (58). Another strength of our study is the use of the EDR. The participants are asked to record all foods and beverages at the time it occurs, to minimize dependence on memory. Although the participant's reactivity behavior may affect the EDR (30), it was shown that food records provide better estimates of protein and energy intake compared to 24-h dietary recalls and a food frequency questionnaire (59). Moreover, the compliance with the supplement intake was assessed by weighing the amount of powder that the participant returned to the study visit. It must therefore be reported that this measurement is only an indication of compliance and not a measure of effective consumption.

One limitation of this study is the limited number of participants who received the protein supplement $(n=20)$. The participants represent a range of sarcopenia stages. A relative high number of participants dropped-out after randomization. As a result of these three points, the representability of this study sample may be implicated and potentially limits the external validity of the proof of concept. Concerning the methodology, a few topics can be discussed. First, protein supplementation focused on the main meals, whilst snack 3 (before bedtime) was only supplemented if the main meals could insufficiently be increased. It could be argued that protein intake before bedtime could have been included to increase the fractional synthetic rate during overnight recovery (60). Second, the analysis of the amino-acid composition of the dietary protein 
intake in this study mainly focuses on leucine, given its role in the development of muscle tissue MPS in older adults (61). However, since the stimulation of MPS by leucine also depends on the availability of other amino acids (62), these could also be discussed in light of their recommended amount in future studies. Third, the use of the EDR is the best available method to assess protein intake for the purpose of this study, but the validity of this technique can be questioned since it is based on estimates and not quantitative measures. Fourth, the effect of other interventions such as exercise or PUFA's supplementation was not taken into account for the analysis of the regular dietary intake or the effect of supplementation on regular dietary intake nor did we assess effect of the different interventions on sarcopenia status and functional outcomes. Recent studies found that sarcopenia was more frequent in community-dwelling adults with low levels of leucine and essential amino acids in the blood (63), and associated with decreased consumption of protein compared to non-sarcopenic adults (64). This was not assessed in this study yet can be a focus for further research.

\section{Means for Practice}

The results of this study showed that personalized protein supplementation is needed to achieve recommended dietary protein intake, and showed to be achievable to improve protein quantity, quality and distribution in communitydwelling (pre)sarcopenic older adults (16). Since diet is a modifiable risk factor for sarcopenia (65), influencing nutritional status may influence muscle functioning and therefore for example sarcopenia, a syndrome that increases the health care expenditures with $\$ 900 /$ person/year (66). In that respect, nutritional adjustments can be considered as relatively inexpensive interventions, for example by dieticians. Consequently, the effect of personalized protein supplementation on outcomes such as sarcopenia or physical functioning should be one of the focal points of further research.

\section{DATA AVAILABILITY STATEMENT}

The raw data supporting the conclusions of this article will be made available by the authors, without undue reservation.

\section{ETHICS STATEMENT}

The studies involving human participants were reviewed and approved by The study was approved by KU Leuven/UZ Leuven

\section{REFERENCES}

1. Cruz-Jentoft AJ, Baeyens JP, Bauer JM, Boirie Y, Cederholm T, Landi F, et al. Sarcopenia: European consensus on definition and diagnosis: Report of the European Working Group on Sarcopenia in Older People. Age Ageing. (2010) 39:412-23. doi: 10.1093/ageing/afq 034

2. Cruz-Jentoft AJ, Bahat G, Bauer J, Boirie Y, Bruyere O, Cederholm T, et al. Sarcopenia: revised European consensus on definition and diagnosis. Age Ageing. (2019) 48:16-31. doi: 10.1093/ageing/afy169
Ethics Committee (s60763). The patients/participants provided their written informed consent to participate in this study.

\section{AUTHOR CONTRIBUTIONS}

LD, SV, KK, JT, and EG: conceptualization. LD and JD: data curation. LD and JD: investigation. LD, JD, JT, CM, and EG: methodology. EG: supervision. LD and EG: writing - original draft. LD, JD, SV, KK, JT, CM, and EG: writing - review and editing. All authors contributed to the article and approved the submitted version. A version of this article previously appeared online in the $\mathrm{PhD}$ thesis of $\mathrm{LD}(67)$.

\section{FUNDING}

We received support from Nestlé Health Science Belgium (discounted rate for the products Resource ${ }^{\circledR}$ Instant Protein and Resource ${ }^{\circledR}$ Maltodextrin). The ENHANce project is funded by a project grant (G099721N) of the Research Foundation Flanders (FWO).

\section{ACKNOWLEDGMENTS}

We would like to thank all students from KU Leuven and UCLL that assisted in the ENHANce study during the last few years for their meaningful contributions.

\section{SUPPLEMENTARY MATERIAL}

The Supplementary Material for this article can be found online at: https://www.frontiersin.org/articles/10.3389/fnut.2021. 672971/full\#supplementary-material

Supplementary Figure 1 | Overview of assessment moments in the ENHANce study relevant for this study. The moments at which the data was collected for the use in this study are indicated with an orange arrow. EDR, estimated dietary records. Symbols from https://icon-library.net.

Supplementary Figure 2 | Overview of individual protein supplementation (g) per meal moment $(n=20)$.

Supplementary Table 1 | Nutritional content of protein and placebo supplement.

Supplementary Table 2 | Distribution of protein intake (median and interquartile range) based on the four-day EDR of all and subgroup of 20 community-dwelling pre)sarcopenic older adults receiving protein supplement.

Supplementary Table 3 | Total intake of amino acids (g) per day (median and interquartile range) of subgroup of 20 community-dwelling (pre)sarcopenic older adults receiving protein supplement. 
5. Wilkinson DJ, Hossain T, Hill DS, Phillips BE, Crossland H, Williams J, et al. Effects of leucine and its metabolite beta-hydroxy-beta-methylbutyrate on human skeletal muscle protein metabolism. J Physiol. (2013) 591:291123. doi: 10.1113/jphysiol.2013.253203

6. Chanet A, Verlaan S, Salles J, Giraudet C, Patrac V, Pidou V, et al. Supplementing breakfast with a vitamin D and leucine-enriched whey protein medical nutrition drink enhances postprandial muscle protein synthesis and muscle mass in healthy older men. J Nutr. (2017) 147:226271. doi: $10.3945 /$ jn. 117.252510

7. Dorhout BG, Overdevest E, Tieland M, Nicolaou M, Weijs PJM, Snijder $\mathrm{MB}$, et al. Sarcopenia and its relation to protein intake across older ethnic populations in the Netherlands: the HELIUS study. Ethnicity Health. (2020). doi: 10.1080/13557858.2020.1814207. [Epub ahead of print].

8. Granic A, Mendonça N, Sayer AA, Hill TR, Davies K, Siervo M, et al. Effects of dietary patterns and low protein intake on sarcopenia risk in the very old: the Newcastle 85+ study. Clin Nutr. (2020) 39:16673. doi: 10.1016/j.clnu.2019.01.009

9. Kumar V, Selby A, Rankin D, Patel R, Atherton P, Hildebrandt W, et al. Age-related differences in the dose-response relationship of muscle protein synthesis to resistance exercise in young and old men. J Physiol. (2009) 587:211-7. doi: 10.1113/jphysiol.2008.164483

10. Campbell WW, Trappe TA, Wolfe RR, Evans WJ. The recommended dietary allowance for protein may not be adequate for older people to maintain skeletal muscle. J Gerontol Ser A Biol Sci Med Sci. (2001) 56:M373M80. doi: 10.1093/gerona/56.6.M373

11. Landi F, Calvani R, Tosato M, Martone AM, Ortolani E, Savera G, et al. Protein intake and muscle health in old age: from biological plausibility to clinical evidence. Nutrients. (2016) 8:295. doi: 10.3390/nu8050295

12. Wall BT, Cermak NM, van Loon LJ. Dietary protein considerations to support active aging. Sports Med. (2014) 44(Suppl 2):S185S94. doi: 10.1007/s40279-014-0258-7

13. Paddon-Jones D, Campbell WW, Jacques PF, Kritchevsky SB, Moore LL, Rodriguez NR, et al. Protein and healthy aging. Am J Clin Nutr. (2015) 101:1339s-45s. doi: 10.3945/ajcn.114.084061

14. Hickson M. Nutritional interventions in sarcopenia: a critical review. Proc Nutr Soc. (2015) 74:378-86. doi: 10.1017/S0029665115002049

15. Campbell WW, Crim MC, Dallal GE, Young VR, Evans WJ. Increased protein requirements in elderly people: new data and retrospective reassessments. Am J Clin Nutr. (1994) 60:501-9. doi: 10.1093/ajcn/60.4.501

16. Bauer J. Evidence-based recommendations for optimal dietary protein intake in older people: a position paper from the PROT-AGE Study Group. J Am Med Dir Assoc. (2013) 14:542-59. doi: 10.1016/j.jamda.2013.05.021

17. Volkert D, Beck AM, Cederholm T, Cruz-Jentoft A, Goisser S, Hooper L, et al. ESPEN guideline on clinical nutrition and hydration in geriatrics. Clin Nutr. (2019) 38:10-47. doi: 10.1016/j.clnu.2018.05.024

18. Bollwein J, Diekmann R, Kaiser MJ, Bauer JM, Uter W, Sieber CC, et al. Distribution but not amount of protein intake is associated with frailty: a cross-sectional investigation in the region of Nurnberg. Nutr J. (2013) 12:109. doi: 10.1186/1475-2891-12-109

19. Tieland M, Borgonjen-Van den Berg KJ, van Loon LJ, de Groot LC. Dietary protein intake in community-dwelling, frail, and institutionalized elderly people: scope for improvement. Eur J Nutr. (2012) 51:1739. doi: 10.1007/s00394-011-0203-6

20. Dedeyne L, Dupont J, Koppo K, Verschueren S, Tournoy J, Gielen E. Exercise and Nutrition for Healthy AgeiNg (ENHANce) project effects and mechanisms of action of combined anabolic interventions to improve physical functioning in sarcopenic older adults: study protocol of a triple blinded, randomized controlled trial. BMC Geriatr. (2020) 20:532. doi: 10.1186/s12877-020-01900-5

21. Folstein MF, Folstein SE, McHugh PR. "Mini-mental state." A practical method for grading the cognitive state of patients for the clinician. J Psychiatr Res. (1975) 12:189-98. doi: 10.1016/0022-3956(75)90026-6

22. Huhmann MB, Perez V, Alexander DD, Thomas DR. A self-completed nutrition screening tool for community-dwelling older adults with high reliability: a comparison study. J Nutr Health Aging. (2013) 17:33944. doi: 10.1007/s12603-013-0015-x

23. Fess EE. American society of hand therapists. J Hand Surg. (1983) 8:6257. doi: 10.1016/S0363-5023(83)80141-5
24. Fried LP, Tangen CM, Walston J, Newman AB, Hirsch C, Gottdiener J, et al. Frailty in older adultsevidence for a phenotype. J Gerontol Ser A. (2001) 56:M146-M57. doi: 10.1093/gerona/56.3.M146

25. Roberts HC, Denison HJ, Martin HJ, Patel HP, Syddall H, Cooper C, et al. A review of the measurement of grip strength in clinical and epidemiological studies: towards a standardised approach. Age Ageing. (2011) 40:4239. doi: 10.1093/ageing/afr051

26. BCGuidelines.ca. Frailty in Older Adults: Early Identification and Management (2017).

27. Guralnik JM, Ferrucci L, Pieper CF, Leveille SG, Markides KS, Ostir GV, et al. Lower extremity function and subsequent disability: consistency across studies, predictive models, and value of gait speed alone compared with the short physical performance battery. J Gerontol Ser A Biol Sci Med Sci. (2000) 55:M221-M31. doi: 10.1093/gerona/55.4.M221

28. Beaton GH, Milner J, Corey P, McGuire V, Cousins M, Stewart E, et al. Sources of variance in 24-hour dietary recall data: implications for nutrition study design and interpretation. Am J Clin Nutr. (1979) 32:254659. doi: 10.1093/ajcn/32.12.2546

29. Nelson M, Black AE, Morris JA, Cole TJ. Between- and within-subject variation in nutrient intake from infancy to old age: estimating the number of days required to rank dietary intakes with desired precision. Am J Clin Nutr. (1989) 50:155-67. doi: 10.1093/ajcn/50.1.155

30. Thompson FE, Kirkpatrick SI, Subar AF, Reedy J, Schap TE, Wilson MM, et al. The National Cancer Institute's Dietary Assessment Primer: a resource for diet research. J Acad Nutr Diet. (2015) 115:198695. doi: 10.1016/j.jand.2015.08.016

31. NUBEL v.z.w. De Belgische Voedingsmiddelentabel (2020). Available online at: http://www.nubel.com/nl/voedingsmiddelentabel.html (accessed November 19, 2020).

32. U.S. Department of Agriculture. FoodData Central (2019). Available online at: https://fdc.nal.usda.gov/ (accessed November 19, 2020).

33. Rijksinstituut voor Volksgezondheid en Milieu. NEDERLANDS VOEDINGSSTOFFENBESTAND (NEVO) (2016). Available online at: https:// nevo-online.rivm.nl/ (accessed November 19, 2020).

34. Efsa Panel on Dietetic Products Nutrition Allergies. Scientific opinion on dietary reference values for energy. EFSA J. (2013) 11:3005. doi: 10.2903/j.efsa.2013.3005

35. Watson RR. Nutrition in the Aged. Boca Raton, FL, CRC Press Taylor and Francis Group (2009).

36. Lachat C, Hawwash D, Ocke MC, Berg C, Forsum E, Hornell $\mathrm{A}$, et al. Strengthening the reporting of observational studies in epidemiology-nutritional epidemiology (STROBE-nut): an extension of the STROBE statement. PLoS Med. (2016) 13:e1002036. doi: 10.1371/journal.pmed.1002036

37. Layman DK, Anthony TG, Rasmussen BB, Adams SH, Lynch CJ, Brinkworth GD, et al. Defining meal requirements for protein to optimize metabolic roles of amino acids. Am J Clin Nutr. (2015) 101:1330S-8S. doi: 10.3945/ajcn.114.084053

38. Phillips SM, Chevalier S, Leidy HJ. Protein "requirements" beyond the RDA: implications for optimizing health. Appl Physiol Nutr Metab. (2016) 41:56572. doi: 10.1139/apnm-2015-0550

39. Rafii M, Chapman K, Owens J, Elango R, Campbell WW, Ball RO, et al. Dietary protein requirement of female adults $>65$ years determined by the indicator amino acid oxidation technique is higher than current recommendations. J Nutr. (2014) 145:18-24. doi: 10.3945/jn.114.197517

40. Rafii M, Chapman K, Elango R, Campbell WW, Ball RO, Pencharz PB, et al. Dietary protein requirement of men $>65$ years old determined by the indicator amino acid oxidation technique is higher than the current estimated average requirement. J Nutr. (2016) 146:681-7. doi: 10.3945/jn.115.225 631

41. Tieland M, Franssen R, Dullemeijer C, van Dronkelaar C, Kyung Kim H, Ispoglou $\mathrm{T}$, et al. The impact of dietary protein or amino acid supplementation on muscle mass and strength in elderly people: individual participant data and meta-analysis of RCT's. J Nutr Health Aging. (2017) 21:9941001. doi: 10.1007/s12603-017-0896-1

42. Kim I-Y, Schutzler S, Schrader A, Spencer H, Kortebein P, Deutz NEP, et al. Quantity of dietary protein intake, but not pattern of intake, affects net protein balance primarily through differences in protein 
synthesis in older adults. Am J Physiol Endocrinol Metab. (2015) 308:E21E8. doi: 10.1152/ajpendo.00382.2014

43. Mitchell CJ, Milan AM, Mitchell SM, Zeng N, Ramzan F, Sharma P, et al. The effects of dietary protein intake on appendicular lean mass and muscle function in elderly men: a 10-wk randomized controlled trial. Am J Clin Nutr. (2017) 106:1375-83. doi: 10.3945/ajcn.117.160325

44. Loenneke JP, Loprinzi PD, Murphy CH, Phillips SM. Per meal dose and frequency of protein consumption is associated with lean mass and muscle performance. Clin Nutr. (2016) 35:1506-11. doi: 10.1016/j.clnu.2016.04.002

45. Murphy CH, Saddler NI, Devries MC, McGlory C, Baker SK, Phillips SM. Leucine supplementation enhances integrative myofibrillar protein synthesis in free-living older men consuming lower- and higher-protein diets: a parallel-group crossover study. Am J Clin Nutr. (2016) 104:1594606. doi: $10.3945 /$ ajen.116.136424

46. Rousset S, Patureau Mirand P, Brandolini M, Martin JF, Boirie Y. Daily protein intakes and eating patterns in young and elderly French. Br J Nutr. (2003) 90:1107-15. doi: 10.1079/BJN20031004

47. Nygård LK, Dahl L, Mundal I, Šaltyte Benth J, Rokstad AMM. Protein intake, protein mealtime distribution and seafood consumption in elderly Norwegians: associations with physical function and strength. Geriatrics. (2020) 5:100. doi: 10.3390/geriatrics5040100

48. Deutz NE, Wolfe RR. Is there a maximal anabolic response to protein intake with a meal? Clin Nutr. (2013) 32:309-13. doi: 10.1016/j.clnu.2012.11.018

49. van Vliet S, Burd NA, van Loon LJ. The skeletal muscle anabolic response to plant- versus animal-based protein consumption. J Nutr. (2015) 145:198191. doi: 10.3945/jn.114.204305

50. Berner LA, Becker G, Wise M, Doi J. Characterization of dietary protein among older adults in the United States: amount, animal sources, and meal patterns. J Acad Nutr Diet. (2013) 113:809-15. doi: 10.1016/j.jand.2013.01.014

51. Riazi R, Wykes LJ, Ball RO, Pencharz PB. The total branched-chain amino acid requirement in young healthy adult men determined by indicator amino acid oxidation by use of L-[1-13C]phenylalanine. J Nutr. (2003) 133:13839. doi: $10.1093 / \mathrm{jn} / 133.5 .1383$

52. Institute of Medicine Food and Nutrition Board. Dietary Rererence Intakes: Energy, Carbohydrate, Fiber, Fat, Fatty Acids, Cholesterol, Protein and Amino Acids. Washington, DC: National Academies Press (2005).

53. Gingrich A, Spiegel A, Kob R, Schoene D, Skurk T, Hauner H, et al. Amount, distribution, and quality of protein intake are not associated with muscle mass, strength, and power in healthy older adults without functional limitations-an enable study. Nutrients. (2017) 9:1358. doi: 10.3390/nu 9121358

54. WHO. Protein and Amino Acid Requirements in Human Nutrition. World Health Organization Technical Report Series (2007).

55. Hengeveld LM, Wijnhoven HAH, Olthof MR, Brouwer IA, Simonsick EM, Kritchevsky SB, et al. Prospective associations of diet quality with incident frailty in older adults: the health, aging, and body composition study. J Am Geriatr Soc. (2019) 67:1835-42. doi: 10.1111/jgs.16011

56. Lee $\mathrm{PH}$, Chan CW. Energy intake, energy required and mortality in an older population. Public Health Nutr. (2016) 19:317884. doi: $10.1017 /$ S1368980016001750

57. Dijxhoorn DN, VE IJ-H, Wanten GJA, van den Berg MGA. Strategies to increase protein intake at mealtimes through a novel high-frequency food service in hospitalized patients. Eur J Clin Nutr. (2019) 73:9106. doi: 10.1038/s41430-018-0288-6

58. Steenackers N, Gesquiere I, Matthys C. The relevance of dietary protein after bariatric surgery: what do we know? Curr Opin Clin Nutr Metab Care. (2018) 21:58-63. doi: 10.1097/MCO.0000000000000437
59. Prentice RL, Mossavar-Rahmani Y, Huang Y, Van Horn L, Beresford SAA, Caan B, et al. Evaluation and comparison of food records, recalls, and frequencies for energy and protein assessment by using recovery biomarkers. Am J Epidemiol. (2011) 174:591-603. doi: 10.1093/aje/kwr140

60. Res PT, Groen B, Pennings B, Beelen M, Wallis GA, Gijsen AP, et al. Protein ingestion before sleep improves postexercise overnight recovery. Med Sci Sports Exerc. (2012) 44:1560-9. doi: 10.1249/MSS.0b013e31824cc363

61. Katsanos CS, Kobayashi H, Sheffield-Moore M, Aarsland A, Wolfe RR. A high proportion of leucine is required for optimal stimulation of the rate of muscle protein synthesis by essential amino acids in the elderly. Am J Physiol Endocrinol Metab. (2006) 291:E381-E7. doi: 10.1152/ajpendo.00488.2005

62. Wilson FA, Suryawan A, Gazzaneo MC, Orellana RA, Nguyen HV, Davis TA. Stimulation of muscle protein synthesis by prolonged parenteral infusion of leucine is dependent on amino acid availability in neonatal pigs. J Nutr. (2010) 140:264-70. doi: 10.3945/jn.109.113621

63. Ter Borg S, Luiking YC, van Helvoort A, Boirie Y, Schols J, de Groot C. Low levels of branched chain amino acids, eicosapentaenoic acid and micronutrients are associated with low muscle mass, strength and function in community-dwelling older adults. J Nutr Health Aging. (2019) 23:2734. doi: 10.1007/s12603-018-1108-3

64. Verlaan S, Aspray TJ, Bauer JM, Cederholm T, Hemsworth J, Hill TR, et al. Nutritional status, body composition, and quality of life in communitydwelling sarcopenic and non-sarcopenic older adults: a case-control study. Clin Nutr. (2017) 36:267-74. doi: 10.1016/j.clnu.2015.11.013

65. Baum JI, Kim I-Y, Wolfe RR. Protein consumption and the elderly: what is the optimal level of intake? Nutrients. (2016) 8:359. doi: 10.3390/nu8060359

66. Janssen I, Shepard DS, Katzmarzyk PT, Roubenoff R. The healthcare costs of sarcopenia in the United States. J Am Geriatr Soc. (2004) 52:805. doi: 10.1111/j.1532-5415.2004.52014.x

67. Dedeyne L. Development and Evaluation of a Program for the Treatment of Sarcopenia in Community-Dwelling Older Adults. The Exercise and Nutrition for Healthy AgeiNg (ENHANce) Study (PhD Thesis). KU Leuven, Leuven (2020).

Conflict of Interest: JD received a fellowship grant (11A9320N) from Research Foundation Flanders (FWO). JT: speaker's fees from Nutricia. EG: consultancies/advisory boards and/or speaker's fees from Amgen, Sandoz, Takeda, UCB

The remaining authors declare that the research was conducted in the absence of any commercial or financial relationships that could be construed as a potential conflict of interest.

Publisher's Note: All claims expressed in this article are solely those of the authors and do not necessarily represent those of their affiliated organizations, or those of the publisher, the editors and the reviewers. Any product that may be evaluated in this article, or claim that may be made by its manufacturer, is not guaranteed or endorsed by the publisher.

Copyright $\odot 2021$ Dedeyne, Dupont, Verschueren, Koppo, Tournoy, Matthys and Gielen. This is an open-access article distributed under the terms of the Creative Commons Attribution License (CC BY). The use, distribution or reproduction in other forums is permitted, provided the original author(s) and the copyright owner(s) are credited and that the original publication in this journal is cited, in accordance with accepted academic practice. No use, distribution or reproduction is permitted which does not comply with these terms. 